\section{Case Reports in Ophthalmology}

Case Rep Ophthalmol 2017;8:301-307

This article is licensed under the Creative Commons Attribution-NonCommercial 4.0 International License (CC BY-NC) (http://www.karger.com/Services/OpenAccessLicense). Usage and distribution for commercial purposes requires written permission.

\title{
A Case of Childhood-Onset Giant Cell Tumor that Caused Optic Nerve Atrophy in Both Eyes
}

\author{
Masahiro Tonari ${ }^{\mathrm{a}}$ Junko Matsuo ${ }^{\mathrm{a}}$ Hidehiro Oku$^{\mathrm{a}}$ Jun Sugasawa ${ }^{\mathrm{a}}$ \\ Tsunehiko Ikeda $^{a}$ Kazunori Tatsuzawa ${ }^{b}$ Tomoaki Fujita ${ }^{b}$ \\ a Department of Ophthalmology, Osaka Medical College, Takatsuki, Japan; ${ }^{\mathrm{b}}$ Department of \\ Neurosurgery, Kyoto Prefectural University of Medicine, Kyoto, Japan
}

\section{Keywords}

Giant cell tumor · Sphenoid sinus · Ethmoid sinus · Optic atrophy

\begin{abstract}
Purpose: The purpose of this study was to report the case of a female patient who had a giant cell tumor in the paranasal sinus during childhood, and while undergoing multiple resection surgeries experienced optic atrophy in both eyes. Case Presentation: This study involved a 35-year-old woman who was previously diagnosed with a giant cell tumor of the paranasal sinus bone at age 13. A CT scan revealed a large tumor extending from the sphenoid sinus to the ethmoid sinus. At age 14, a tumor resection was performed in conjunction with radiation therapy. However, after resection and radiation therapy there were repeated recurrences, and additional resections were performed. Ophthalmically, there was marked optical atrophy in both eyes, and Goldmann visual field perimetry revealed that only the arcuate peripheral area remained on the nasal side of the right eye, and that there were dark spots in the paracentral area of the left eye. Conclusions: In this case, a large giant cell tumor occurred in the sphenoid sinus and ethmoid sinus during childhood, and it is thought that optic atrophy was caused by compressive optic neuropathy. The sphenoid sinus and ethmoid sinuses are anatomically close to the optic nerve, and when a tumor grows larger at this site it can easily put pressure on the optic nerve. Therefore, early detection and treatment are important.




\section{Introduction}

Pathologically, "giant cell tumor" is a general term for osteoclast-like multinucleated giant cells and is roughly divided into the categories of osteoclastoma and giant cell tumor. Osteoclastomas occur most often in the long bones of the limbs [1] but in rare cases can occur in the cranium. Giant cell tumors that occur in the cranium are reportedly most common in the sphenoid bone $[2,3]$. Here we report the case of a female patient with a giant cell tumor that occurred in the bone of the paranasal sinus during childhood, and who, after undergoing resection surgery, underwent multiple additional removal surgeries, during the course of which she experienced optic nerve atrophy in both eyes.

\section{Case Report}

We report the case of a 35-year-old female. Her chief complaints were vision disorder in both eyes, disturbance of the visual field, and a request for ophthalmological examination.

\section{Medical History}

After being diagnosed with a giant cell tumor at age 13, the patient noticed a decline in visual acuity in both eyes and visual field defects. At that age, her corrected visual acuity was 0.1 in her right eye and 0.5 in her left eye. A CT scan at that time revealed a large tumor from the sphenoid sinus to the ethmoid sinus, and the state of the intracranial optic nerves was unclear (Fig. 1a, b). At age 14, tumor removal was performed at the Kyoto Prefectural Medical College of Otolaryngology, and partial resection of the tumor was performed 1 month later at the same hospital's neurosurgery department together with radiation therapy $(3,168$ rad). Three months later, a sphenoid invasion resection was performed in addition to radiation therapy $(1,408 \mathrm{rad})$ during reoperation at the hospital's otorhinology unit. At that time, a CT scan image showed that most of the tumor had been removed, but some remained within the sphenoid sinus (Fig. 2). At age 16, an additional resection was performed at the same otorhinology unit, with later follow-up observations. At age 23, MRI oblique T1-weighted imaging showed the remnants of a giant cell tumor in her sphenoid sinus (Fig. 3a, b). After that, no particularly significant change in the condition of the tumor was observed.

When the patient was 24 years of age, we were asked to perform an ophthalmological examination. Upon examination, her visual acuity was $0.02(0.03 \times \mathrm{S}-1.50=\mathrm{C}-2.00 \mathrm{~A} \times$ $\left.110^{\circ}\right)$ in her right eye and $0.2\left(0.3 \times \mathrm{S}-0.75=\mathrm{C}-1.25 \mathrm{~A} \times 90^{\circ}\right)$ in her left eye. Intraocular pressure was 11 and $13 \mathrm{~mm} \mathrm{Hg}$ in her right and left eye, respectively. In regard to eye position, esotropia was present, measuring 30 prism dpt at near vision and 35 prism dpt at distant vision. A slight abduction failure was observed in her left eye. Moreover, ocular protrusion of $8 \mathrm{~mm}$ in her right eye and $8.5 \mathrm{~mm}$ in her left eye (base $98 \mathrm{~mm}$ ) was observed. No abnormalities of the anterior ocular segment and ocular media were observed, yet the fundus showed marked optic atrophy in both eyes (Fig. 4a, b). There was no depression of the optic discs, and a state of bilateral atrophy was presented. Goldmann visual field perimetry revealed that arcuate peripheral vision remained only on the nasal side of the right eye. Absolute scotomas were observed in 4 locations near the center of the left eye, with relative scotomas within a 20-degree range around it (Fig. 5a, b). Since that time, ophthalmological examinations, including visual field testing, have been performed; however, no obvious changes have been observed. 


\section{Discussion}

The incidence of "giant cell tumor" reportedly accounts for approximately $4 \%$ of primary bone tumors $[2,4]$, and although they are classified as benign, they are characterized by their ease of recurrence compared to other benign osteomas [2]. Giant cell tumors occur most frequently in patients between the ages of 20 and 45 years, and are somewhat more common in women [5]. The location of the occurrence includes the distal end of the femur, the proximal end of the tibia, the distal end of the radius, the proximal end of the humerus, and the sacrum [1]. However, in rare cases, giant cell tumors can also occur in the cranium $[2,3]$. Reportedly, cranium giant cell tumors are extremely rare, and are observed in approximately 1 of every 2,000 giant cell tumor cases [6,7]. Giant cell tumors in the cranium occur most often in the sphenoid bone [8,9], with the temporal bone being the next most frequent location [2,3]. Histologically, because many giant cells resembling osteoclasts are seen, they were known as "osteoclastoma" in the past, but it is thought that the tumors are primarily made up of stromal cells in between giant cells, and it remains unclear what types of cells they originate from [1]. Moreover, the causes due to genetic abnormalities have yet to be elucidated.

Clinical symptoms are considered to be localized pain, swelling, and limitation of joint movement caused by microfractures that accompany a decrease in bone strength. When a pathological fracture occurs, very light trauma may be followed by symptoms of sustained pain over a prolonged period. Giant cell tumors occurring in the cranium show various symptoms depending on the compression site, but X-rays may reveal signs of clear bone structure damage for relatively minor symptoms. When occurring in the sphenoid bone, since cranial nerves II, III, IV, V, and VI are involved, ophthalmic symptoms such as double vision, visual field defects, and eyeball protrusion are most often observed [10,11]. When occurring in the temporal bone, the main symptoms are often otolaryngological symptoms such as dizziness, tinnitus, hearing loss, the feeling of ear fullness, and facial nerve paralysis [12].

Definitive diagnosis requires that a biopsy and histology be performed. In many cases, blood tests show high levels of acid phosphatase, and this is considered to be effective to some extent as a marker indicating the degree of therapeutic effect [13].

The first choice of treatment is surgical tumor resection [14]. When surgery is difficult, radiation therapy is sometimes performed; however, the effectiveness varies [15, 16]. In cases that undergo surgery, and unlike regular benign bone tumors, semi-extensive resection or extensive resection is performed. Although a giant cell tumor is a benign tumor since it is unusually highly active locally, simple surgical removal will result in recurrence in nearly $50 \%$ of cases. Therefore, after the tumor is removed, the surrounding bone where the tumor was found is scraped, followed in some cases by treatment of the surrounding bone with ethanol, phenol, or similar, in order to remove any remaining tumor cells.

A large giant cell tumor occurs most often in the long bones of the limbs, but can also occur in the cranium in rare cases. In our patient, as can be seen in CT images from the time of the initial surgery, it occurred in the sphenoid sinus and ethmoid sinus during childhood, and it is thought that optic atrophy was caused by compressive optic neuropathy. Regarding the possibility of radiation retinopathy, it was deemed negative due to the fact that there had been no findings such as retinal hemorrhages and/or soft exudations during the follow-up periods. The esotropia seen in this case is thought to be due to abductive nerve paralysis. The sphenoid sinus and ethmoid sinuses are anatomically close to the optic nerve, and when a tumor at this site grows larger it can easily put pressure on the optic nerve. As in the case 
in this study, where there is a high risk of marked optical atrophy due to prolonged pressure, it is necessary to remove the tumor at an early stage in order to release the pressure. In order to maintain the remaining visual function, it is important to perform periodic follow-up examinations with diagnostic imaging such as MRI in order to check for residual tumor growth.

\section{Acknowledgment}

The authors wish to thank John Bush for editing the manuscript.

\section{Statement of Ethics}

This case study was approved by the Ethics Committee of Osaka Medical College.

\section{Disclosure Statement}

There are no conflicts of interest to report for all authors.

\section{References}

1 McCarthy EF: Giant-cell tumor of bone: an historical perspective. Clin Orthop Relat Res 1980;153:1425.

-2 Glasscock ME 3rd, Hunt WE: Giant-cell tumor of the sphenoid and temporal bones. Laryngoscope 1974;84:1181-1187.

3 Bertoni F, Unni KK, Beabout JW, Ebersold MJ: Giant cell tumor of the skull. Cancer 1992;70:1124-1132.

4 McGrath PJ: Giant-cell tumour of bone: an analysis of fifty-two cases. J Bone Joint Surg Br 1972;54:216229.

-5 Zelig S, Eilon A, Deutsch E, Ariel I: Giant cell tumor of the temporal bone. A case report. ORL J Otorhinolaryngol Relat Spec 1982;44:318-322.

-6 Dahlin DC, Cupps RE, Johnson EW Jr: Giant-cell tumor: a study of 195 cases. Cancer 1970;25:10611070.

7 Eller JL, Decker JT, Brittis AL: Roentgen therapy for a giant cell tumor of the sphenoid bone. A case report. Radiol Clin Biol 1968;37:36-44.

-8 Chatterjee D, Gupta K, Singla N, Kapoor A: Sphenoid bone: a rare site for giant cell tumor - case report with literature review. Clin Neuropathol 2016;35:385-388.

-9 Kioumehr F, Rooholamini SA, Yaghmai I, Hoover L, Arnold A, Hannah J, Rodriguez L: Giant-cell tumor of the sphenoid bone: case report and review of the literature. Can Assoc Radiol J 1990;41:155-157.

$\$ 10$ Imai T, Takeda N, Morita M, Koizuka I, Kubo T, Miura K, Nakamae K, Fujioka H: Rotation vector analysis of eye movement in three dimensions with an infrared CCD camera. Acta Otolaryngol 1999;119:24-28.

11 Ohaegbulam SC, Gupta IM: Giant cell tumour of the sphenoid bone with dural extension. J Neurol Neurosurg Psychiatry 1977;40:790-794.

12 McCluggage WG1, McBride GB, Primrose WJ, Cullan J, McNaboe EJ, Bharucha H, Fannin T: Giant cell tumour of the temporal bone presenting as vertigo. J Laryngol Otol 1995;109:538-541.

13 Watanabe N, Matsumoto S, Shimoji T, Ae K, Tanizawa T, Gokita T, Motoi N, Ueno T, Koizumi M: Early evaluation of the therapeutic effect of denosumab on tartrate-resistant acid phosphatase $5 \mathrm{~b}$ expression in a giant cell tumor of bone: a case report. BMC Res Notes 2014;7:608.

14 Rosen MP: General diagnosis case of the day; giant-cell tumor of the temporal bone. AJR Am J Roentgenol 1991;156:1290-1292.

-15 Pearlman AW, Friedman M: Radiation therapy of benign giant cell tumor arising in Paget's disease of bone. Iso-effect recovery study. Am J Roentgenol Radium Ther Nucl Med 1968;102:645-651.

-16 Rosenbloom JS, Storper IS, Aviv JE, Hacein-Bey L, Bruce JN: Giant cell tumors of the jugular foramen. Am J Otolaryngol 1999;20:176-179. 


\section{Case Reports in Ophthalmology}

\begin{tabular}{l|l}
\hline Case Rep Ophthalmol 2017:8:301-307 \\
\hline DOI: 10.1159/000477199 & $\begin{array}{l}\text { ○ 2017 The Author(s). Published by S. Karger AG, Basel } \\
\text { www.karger.com/cop }\end{array}$ \\
\hline
\end{tabular}

Tonari et al.: A Case of Childhood-Onset Giant Cell Tumor that Caused Optic Nerve Atrophy in Both Eyes
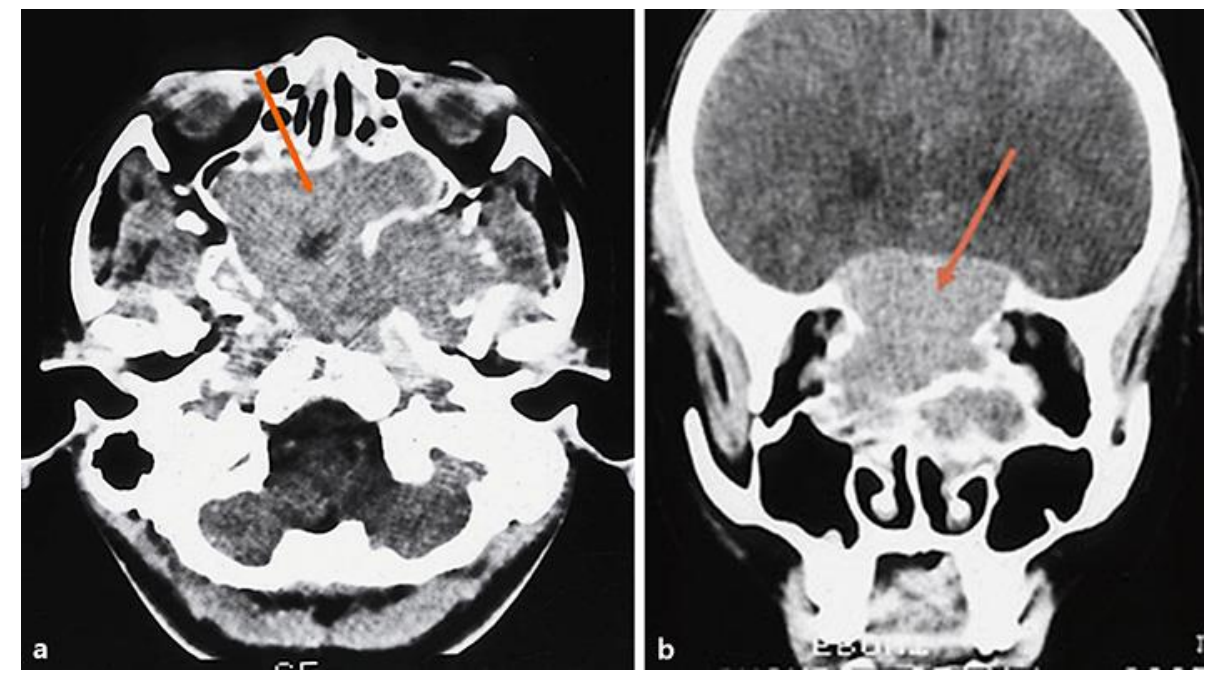

Fig. 1. CT scan orbital findings of the female patient at age 13: horizontal (a), frontal (b). CT scan images at that time revealed a large tumor from the sphenoid sinus to the ethmoid sinus, yet the state of the intracranial optic nerves was unclear. $\mathbf{b}$ The orbits and chiasmal area (arrow) possibly indicate the optic nerve. 


\section{Case Reports in Ophthalmology}

\begin{tabular}{l|l}
\hline Case Rep Ophthalmol 2017;8:301-307 \\
\hline DOI: 10.1159/000477199 & $\begin{array}{l}\text { @ 2017 The Author(s). Published by S. Karger AG, Basel } \\
\text { www.karger.com/cop }\end{array}$ \\
\hline
\end{tabular}

Tonari et al.: A Case of Childhood-Onset Giant Cell Tumor that Caused Optic Nerve Atrophy in Both Eyes

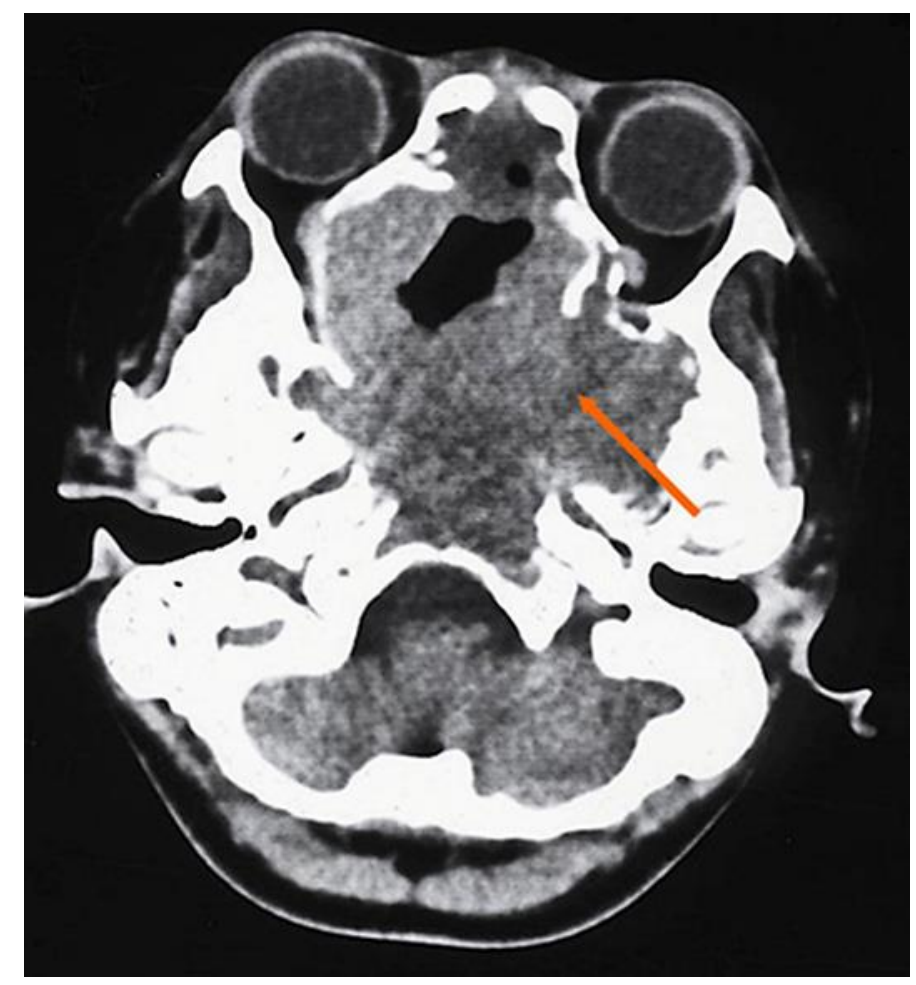

Fig. 2. CT scan image obtained after initial surgical + radiation treatment showing that most of the tumor had been removed, but some remained within the sphenoid sinus.
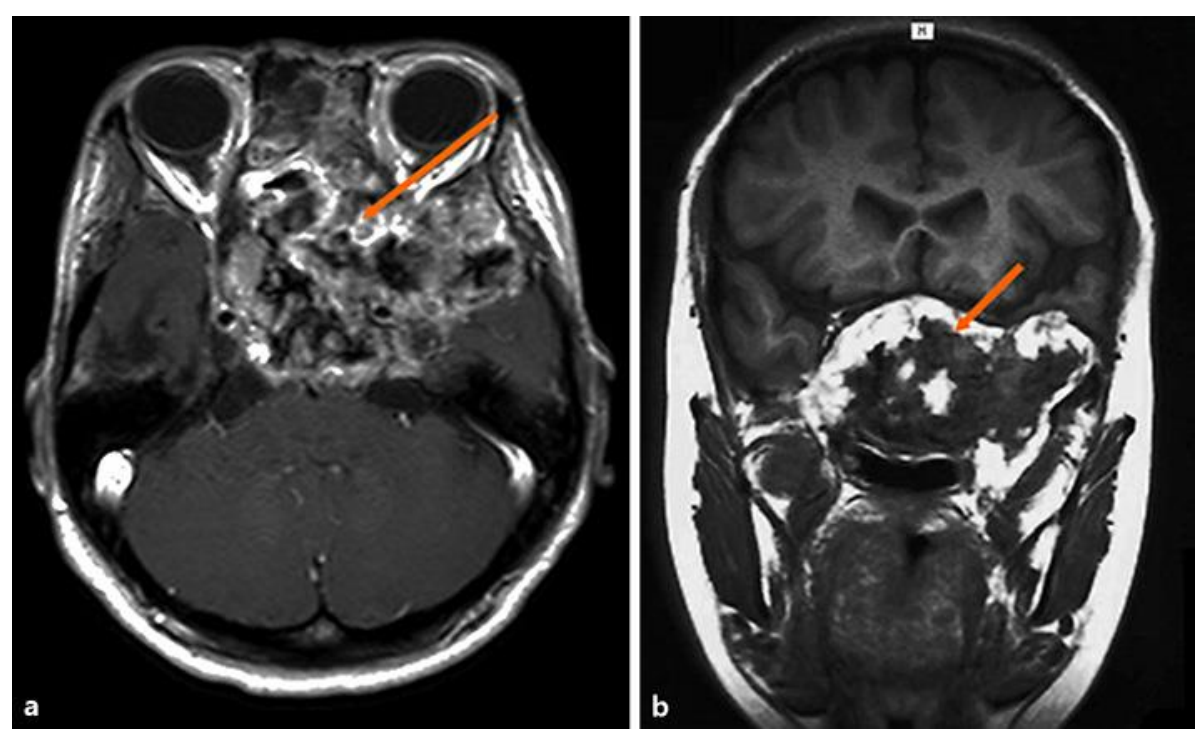

Fig. 3. MRI oblique T1-weighted imaging of the patient at age 23: horizontal (a), frontal (b). The MRI reveals the remnants of a giant cell tumor in the sphenoid sinus. 


\section{Case Reports in Ophthalmology}

\begin{tabular}{l|l}
\hline Case Rep Ophthalmol 2017;8:301-307 \\
\hline DOI: 10.1159/000477199 & $\begin{array}{l}\text { @ 2017 The Author(s). Published by S. Karger AG, Basel } \\
\text { www.karger.com/cop }\end{array}$ \\
\hline
\end{tabular}

Tonari et al.: A Case of Childhood-Onset Giant Cell Tumor that Caused Optic Nerve Atrophy in Both Eyes
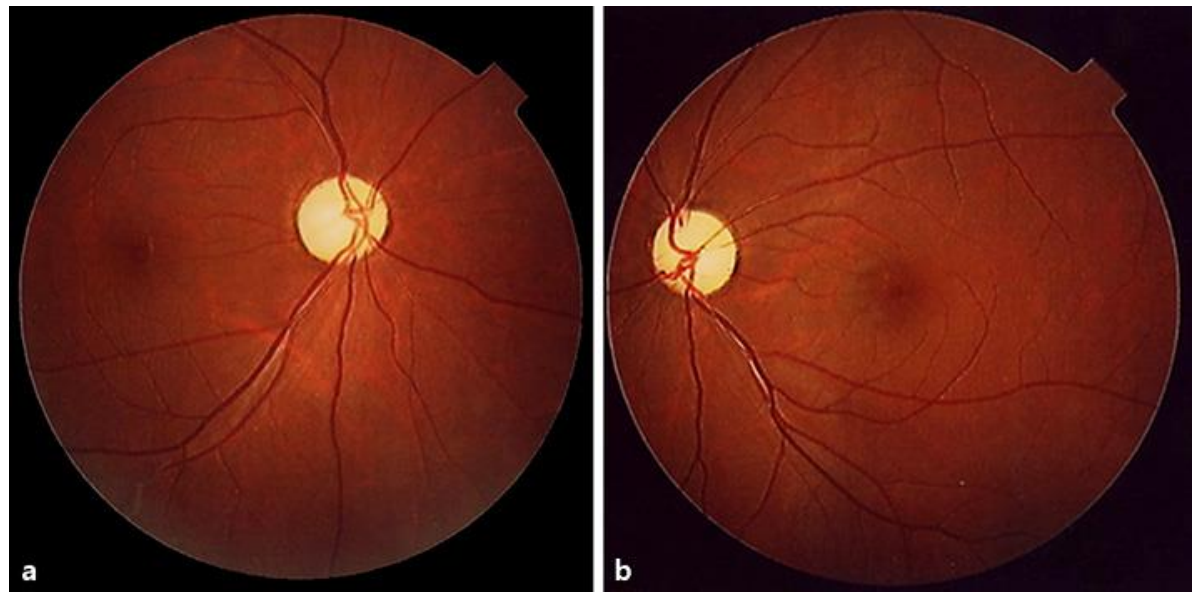

Fig. 4. Fundus photographs of the patient at age 24: right eye (a), left eye (b). Fundus photographs revealed marked optic atrophy in both eyes.
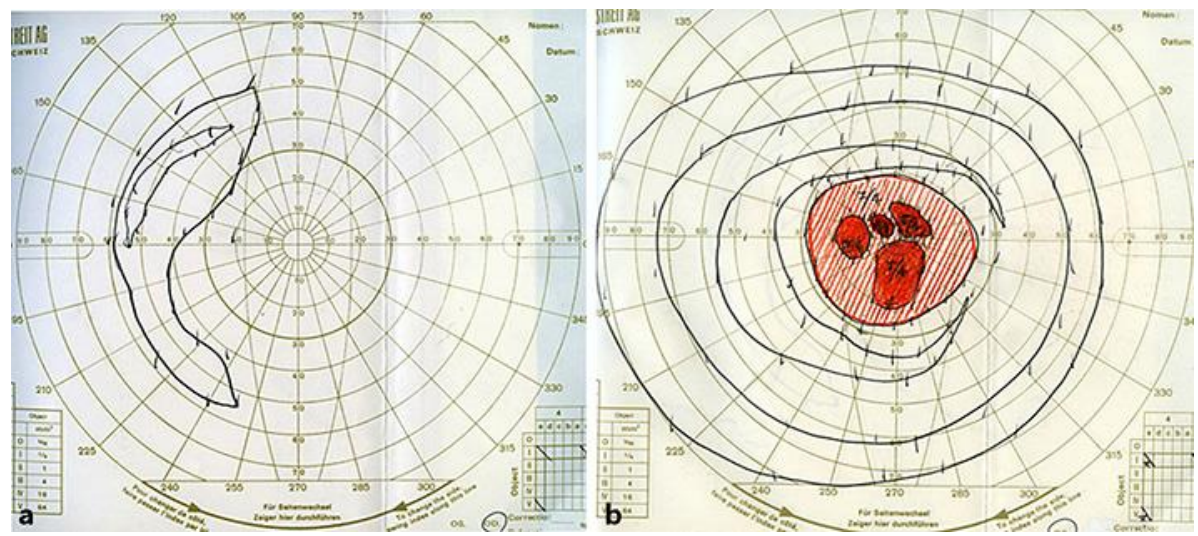

Fig. 5. The results of Goldmann visual field perimetry: right eye (a), left eye (b). Arcuate peripheral vision remained only on the nasal side of the right eye. Absolute scotomas were observed in 4 locations near the center of the left eye, with relative scotomas within a 20-degree range around it. 